\title{
PENGARUH MEDIA ANIMASI DALAM MODEL PEMBELAJARAN INKUIRI TERBIMBING TERHADAP KETERAMPILAN BERPIKIR KRITIS DAN AKTIVITAS BELAJAR PESERTA DIDIK PADA MATERI KESETIMBANGAN KIMIA
}

\author{
Subhan, Pince Salempa ${ }^{1}$, Muhammad Danial ${ }^{2}$ \\ ${ }^{1,2}$ Dosen Program Pascasarjana Universitas Negeri Makassar \\ Email: subhan.cemist@yahoo.com
}

\begin{abstract}
ABSTRAK
Penelitian ini adalah jenis penelitian eksperimen semu yang bertujuan untuk mengetahui pengaruh media animasi dalam model pembelajaran inkuiri terbimbing terhadap keterampilan berpikir kritis dan aktivitas belajar peserta didik kelas XI SMA Negeri 21 Makassar pada materi kesetimbangan kimia. Desain penelitian Post test-Only Control Design. Populasi dalam penelitian ini adalah seluruh peserta didik kelas XI IPA SMA Negeri 21 Makassar yang terdiri dari 8 kelas. Penentuan sampel dilakukan secara random sampling dan kelas XI IPA 2 sebagai kelompok eksperimen dan kelas XI IPA 3 sebagai kelompok kontrol. Data hasil penelitian diperoleh dengan memberikan tes keterampilan berpikir kritis sebanyak 15 soal uraian yang terbagi menjadi 3 kode soal yang telah divalidasi. Teknik analisis data yaitu deskripsi dan pengujian hipotesis terhadap keterampilan berpikir kritis dan aktivitas belajar peserta didik. Hasil penelitian diperoleh deskripsi rata-rata keterampilan berpikir kritis dan standar deviasi untuk kelompok eksperimen adalah 81,35\%, dan 7,78. Sedangkan ratarata keterampilan berpikir kritis dan standar deviasi untuk kelompok kontrol adalah 70,53\% dan 7,27. Hasil pengujian hipotesis dengan uji-t pada taraf signifikan $\alpha=0,05$ diperoleh nilai $t_{\text {hitung }}=180,33$ dan nilai $t_{\text {tabel }}=1,67$. Dengan membandingkan nilai $t_{\text {hitung }} 180,33>t_{\text {tabel }} 1,668$ artinya $\mathrm{H}_{0}$ ditolak dan $\mathrm{H}_{1}$ diterima. Dengan demikian, dapat disimpulkan bahwa terdapat pengaruh media animasi dalam model pembelajaran inkuiri terbimbing terhadap keterampilan berpikir kritis dan aktivitas belajar peserta didik kelas XI SMA Negeri 21 Makassar.
\end{abstract}

Kata kunci: Inkuiri terbimbing, keterampilan berpikir kritis, aktivitas belajar dan kesetimbangan kimia

\begin{abstract}
This research is kind of quasi experimental research which aims to know the influence of animation media in guided inquiry learning model to critical thinking skill and learning activity of class XI student of SMA Negeri 21 Makassar on chemical equilibrium material. Design research Post test-Only Control Design. The population in this study is all students of class XI IPA SMA Negeri 21 Makassar consisting of 8 classes. Sampling was done by random sampling and class XI IPA 2 as experiment group and class XI IPA 3 as control group. Data of research result obtained by giving critical thinking skill test as much as 15 problem description which is divided into 3 validated questions code. Data analysis techniques are description and hypothesis testing of critical thinking skills and learning activities of learners. The result of the research shows that the average of critical thinking skill and standard deviation for experimental group is $81,35 \%$, and 7,78 . While the average critical thinking skills and standard deviation for the control group were 70,53\% and 7,27. The results of hypothesis testing with t-test on the significant level $\alpha=0.05$ obtained $t_{\text {count }}=180,33$ and $t_{\text {table }}=1.67$. By comparing $t_{\text {count }} 180,33>t_{\text {table }} 1,67$ means $H_{0}$ is rejected and $H_{1}$ accepted. Thus, it can be concluded that there is an influence of animation media in guided inquiry
\end{abstract}


learning model of critical thinking skills and learning activities of students of class XI SMA Negeri 21 Makassar.

Keywords: Guided Inquiry, Critical thinking skills, Learning activities and Chemical equilibrium

\section{PENDAHULUAN}

Pelajaran Kimia dikalangan peserta didik masih dianggap sebagai produk, yaitu berupa kumpulan konsep yang harus dihafal sehingga berdampak pada rendahnya keterampilan peserta didik pada aspek kognitif. Aspek kognitif terdiri dari enam aspek yakni mengingat, memahami, menerapkan, menganalisis, mengevaluasi, dan menciptakan. Namun, pada kenyataannya aspek tingkat tinggi seperti analisis mengolah masalah, mengevaluasi, dan menciptakan belum biasa dilatihkan kepada peserta didik. Peserta didik masih kesulitan dalam menerapkan pengetahuan yang dimiliki dalam kehidupan sehari-hari. Selama ini proses pembelajaran kimia masih disampaikan secara konvensional (metode ceramah). Metode ini, peserta didik kurang terlibat secara aktif dalam proses pembelajaran. Dominasi guru dalam proses pembelajaran menyebabkan peserta didik kurang terlatih mengembangkan keterampilan berpikir dalam memecahkan masalah dan menerapkan konsep-konsep yang dipelajari di sekolah ke dalam dunia nyata. Berdasarkan hasil wawancara dengan salah seorang guru kimia dan peserta didik di SMA Negeri 21 Makassar diperoleh bahwa masalah yang kerap ditemukan pada proses pembelajaran kimia adalah rendahnya keterampilan berpikir kritis dan aktivitas belajar peserta didik. Dalam proses pembelajaran peserta didik kurang didorong untuk mengembangkan keterampilan berpikir dan aktivitas belajar. Metode pembelajaran yang digunakan SMA Negeri 21 Makassar masih monoton sehingga membuat peserta didik merasa bosan dan membuat peserta didik jenuh dalam belajar, hal inilah yang menyebabkan peserta didik cenderung menyontek bila diberikan tugas atau saat ulangan.

Wahyuni (2015) berpikir kritis merupakan suatu bentuk pemikiran yang berusaha memahami masalah secara mendalam, memiliki pemikiran terbuka terhadap keputusan dan pendapat orang lain, berusaha mengerti dan mengevaluasi secara benar informasi yang diterima sebelum mengambil keputusan serta mampu menghubungkan antara sebab dan akibat dalam menemukan pemecahan masalah yang dihadapi.

Pembelajaran aktif adalah suatu pembelajaran yang mengajak peserta didik untuk belajar secara aktif. Ketika peserta didik belajar dengan aktif, berarti peserta didik mendominasi aktifitas pembelajaran. Dengan ini peserta didik secara aktif menggunakan otak, baik untuk menemukan ide pokok dari materi, memecahkan persoalan, atau mengaplikasikan apa yang baru mereka pelajari ke dalam satu persoalan yang ada dalam kehidupan nyata. Menurut Oemar Hamalik (2004) aktivitas belajar sangat diperlukan oleh peserta didik dalam proses pembelajaran untuk mendapatkan hasil belajar yang maksimum. Ketika peserta didik pasif atau hanya menerima pelajaran dari guru, ada kecenderungan untuk cepat melupakan apa yang telah diberikan. Oleh sebab itu, diperlukan model pembelajaran yang sesuai agar peserta didik dapat mengikat informasi yang diberikan oleh guru nya dalam setiap proses pembelajaran serta menambah semangat belajar.

Salah satu upaya yang dapat dilakukan untuk meningkatkan keterampilan berpikir kritis dan aktivitas belajar peserta didik selama proses pembelajaran adalah dengan memilih model pembelajaran yang lebih tepat untuk 
digunakan. Salah satu model pembelajaran yang tepat sesuai yang diamanatkan Kurikulum 2013 adalah menggunakan model pembelajaran inkuiri terbimbing. Pembelajaran inkuiri terbimbing dapat mengarahkan peserta didik untuk memecahkan masalah yang diberikan dengan menghubungkan atau mengaplikasikan pengetahuan kimianya untuk dapat meningkatkan keterampilan berpikir kritis dan aktivitas belajar peserta didik. Dalam pembelajaran kimia berpikir kritis dan aktivitas belajar pada peserta didik harus dimunculkan agar pembelajaran kimia lebih bermutu, sehingga peserta didik tidak hanya mampu dalam mengerjakan soal-soal ujian tetapi juga mampu dalam menghasilkan ide-ide (Liliasari, 2005). Untuk dapat mewujudkan hal tersebut dalam pembelajaran kimia harus menggunakan metode ataupun media yang tepat dan bervariasi. Salah satu media yang tepat dan bervariasi dalam menunjang proses pembelajaran peserta didik adalah menggunakan media animasi sebagai sumber belajar (Munandar dalam Sobihi dan Siswanto, 2012).

Media animasi sebagai alat bantu diharapkan peserta didik akan lebih tertarik dan termotivasi dalam kegiatan pembelajaran, karena penyajian materi pembelajaran lebih memotivasi peserta didik. Peran media animasi sebagai proses berpikir kritis peserta didik, topik yang dipelajari secara luas digambarkan dalam media animasi, hasil ini bisa ditafsirkan dengan baik sehingga media animasi memiliki potensi untuk membantu peserta didik memvisualisasikan proses dengan menyediakan informasi yang dibutuhkan (Plass dkk, 1998). Kombinasi teks dan gambar atau animasi pada umumnya menghasilkan hasil belajar yang lebih baik daripada teks saja. Salah satu keunggulan media animasi adalah kemampuan untuk menjelaskan suatu kejadian secara sistematis dalam tiap waktu perubahan. Hal ini sangat membantu peserta didik dalam menjelaskan prosedur dan urutan kejadian secara sistematis dalam tiap waktu perubahan.

Kesetimbangan kimia merupakan salah satu materi yang memiliki bahasan cukup luas sehingga memerlukan keterampilan berpikir peserta didik. Hal ini sesuai dengan pendapat Kadhafi (2013) salah satu materi kimia yang sebagian besar konsepnya abstrak adalah kesetimbangan kimia yang sulit untuk diamati secara kasat mata (tingkat mikroskopis). Karakteristik materi kesetimbangan kimia yang bersifat abstrak ini dapat menyebabkan peserta didik mengalami kesulitan dalam memahami konsep-konsep yang terdapat didalamnya sehingga harus dimunculkan keterampilan berpikir peserta didik agar pembelajaran kimia lebih bermutu. Untuk membantu mengatasi kesulitan memahami konsepkonsep tersebut diperlukan model pembelajaran yang dapat memvisualisasikan materi-materi tersebut sehingga diharapkan peserta didik dapat mengamati gejala-gejala yang terjadi, dapat mengumpulkan data dan menganalisa serta menarik kesimpulan sehingga akan diperoleh konsep-konsep yang bersifat bukan hanya hafalan saja. Model pembelajaran inkuiri terbimbing dengan perangkat pembelajaran media animasi diharapkan mampu membangun pengetahuan peserta didik dengan menemukan sendiri konsep dalam materi kesetimbangan kimia dengan kemampuan berpikir kritis yang telah dibangun pada proses pembelajaran (Rosita, 2013).

Berdasarkan pemaparan diatas, maka rumusan masalah dalam penelitian ini adalah apakah ada pengaruh media animasi dalam model pembelajaran inkuiri terbimbing terhadap keterampilan berpikir kritis dan aktivitas belajar peserta didik kelas XI SMA Negeri 21 Makassar pada materi kesetimbangan Kimia. Adapun tujuan dari penelitian ini dilakukan adalah untuk mengetahui pengaruh media animasi dalam model pembelajaran inkuiri terbimbing terhadap keterampilan berpikir kritis dan aktivitas belajar peserta didik 
kelas XI SMA Negeri 21 Makassar pada materi kesetimbangan Kimia. Penelitian ini diharapkan memberi manfaat antara lain:

1. Bagi peserta didik

Peserta didik diharapkan dapat belajar lebih giat dengan menggunakan media animasi dalam model pembelajaran inkuiri terbimbing.

2. Bagi Pendidik

Pendidik diharapkan mampu membimbing peserta didik dengan inovasi-inovasi media pembelajaran dalam model pembelajaran kurikulum 2013 untuk menghadapi tantangan zaman.

3. Bagi sekolah

Sekolah sebagai lembaga pendidikan diharapkan dapat menjadi tempat untuk melahirkan generasi muda yang berkualitas, dengan menyediakan sarana dan prasarana untuk mengintegrasikan teknologi dalam model pembelajaran.

\section{Model Pembelajaran Inkuiri Terbimbing}

Pembelajaran inkuiri terbimbing adalah suatu pembelajaran bersifat investigasi dimana guru hanya memberikan bahan dan permasalahan untuk diselesaikan. Peserta didik memutuskan sendiri bagaimana cara untuk menyelesaikan permasalahan tersebut (Alan Colburn, 2000). Model pembelajaran inkuiri terbimbing dalam pelaksanaannya membutuhkan peran sumber belajar, seperti media animasi. Pembelajaran inkuiri terbimbing dapat mengarahkan peserta didik untuk memecahkan masalah yang diberikan dengan menghubungkan atau mengaplikasikan pengetahuan kimianya untuk dapat meningkatkan keterampilan berfikir kritis dan aktivitas belajar (Liliasari, 2005).

Sanjaya (2010) media animasi yaitu jenis media yang selain mengandung unsur suara juga mengandung unsur gambar yang dapat dilihat, misalnya rekaman video, film, slide suara, dan lain sebagainya. Manfaat menggunakan media Animasi dalam bentuk video yaitu karena video dapat menggambarkan suatu proses secara tepat yang dapat disaksikan secara berulang-ulang oleh peserta didik. Disamping mendorong dan meningkatkan motivasi, video juga menanamkan sikap dan segi-segi afektif lainnya.

Keterampilan berpikir kritis sangat perlu dan penting untuk dikembangkan pada diri peserta didik. Dengan keterampilan ini diharapkan peserta didik dapat menjadikan hidupnya lebih baik lagi. Rahmawati (2006) mengemukakan pentingnya keterampilan berpikir kritis bagi peserta didik. Ia berpendapat bahwa, hanya ketika kita mengembangkan keterampilan berpikir kritis terhadap mata pelajaran, berarti kita mendidik anak untuk menguji struktur logika dan menguji pengalamannya dari berbagai aspek sehingga pada akhirnya akan menjadikan mereka menjadi orang dewasa yang kritis.

Pembelajaran yang efektif adalah pembelajaran yang menyediakan kesempatan belajar sendiri atau melakukan aktivitas sendiri. Proses pembelajaran yang dilakukan didalam kelas merupakan aktivitas mentransformasikan pengetahuan, sikap, dan ketrampilan (Martinis Yamin, 2007). Aktivitas belajar dapat terwujud apabila peserta didik terlibat belajar secara aktif. Martinis Yamin (2007) mendefinisikan belajar aktif sebagai usaha manusia untuk membangun pengetahuan dalam dirinya. Pembelajaran akan menghasilkan suatu perubahan dan peningkatan kemampuan, pengetahuan dan ketrampilan pada diri peserta didik. Peserta didik mampu menggali kemampuannya dengan rasa ingin tahunya sehingga interaksi yang terjadi akan menjadi pengalaman dan keinginan untuk mengetahui sesuatu yang baru. Adapun jenis-jenis kegiatan aktivitas belajar peserta didik dalam pembelajaran terdiri dari: Peserta didik melihat, peserta didik mengamati, peserta didik mendengar, partisipasi peserta didik, motivasi, ketekunan dan antusiasme peserta didik, hubungan antar peserta didik, hubungan 
peserta didik dengan guru, dan efektifitas pemanfaatan waktu.

Adapun Indikator tercapainya KD pada materi Kesetimbangan kimia adalah:

1. Menjelaskan faktor-faktor yang mempengaruhi arah pergeseran kesetimbangan.

2. Menentukan harga tetapan kesetimbangan dari suatu reaksi kesetimbangan.

3. Menentukan harga derajat disosiasi dari suatu reaksi kesetimbangan.

Berdasarkan landasan teori dan kerangka berpikir diatas, maka Peneliti berhipotesis bahwa ada pengaruh positif media animasi dalam model pembelajaran inkuiri terbimbing terhadap keterampilan berpikir kritis dan aktivitas belajar peserta didik kelas XI SMA Negeri 21 Makassar pada materi kesetimbangan kimia.

\section{METODE PENELITIAN}

Penelitian ini merupakan penelitian eksperimen semu. Desain penelitian yang digunakan yaitu Post test-Only Control Design. Popolasi penelitian ini adalah seluruh peserta didik kelas XI SMA Negeri 21 Makassar Tahun ajaran 2017/2018 yang berjumlah 8 kelas. Pemilihan sampel dalam penelitian ini dilakukan dengan teknik random sampling yaitu pengambilan anggota sampel dari populasi dilakukan secara acak. Sampel pada penelitian ini adalah kelas XI IPA 2 sebagai kelompok eksperimen dan kelas XI IPA 3 sebagai kelompok kontrol

Penelitian ini dilaksanakan pada bulan Desember, semester ganjil Tahun pelajaran 2017/2018 yang bertempat di SMA Negeri 21 Makassar. Penelitian dilakukan sebanyak 4 kali pertemuan dimana 3 kali pertemuan digunakan untuk proses pembelajaran sedangkan 1 kali pertemuan untuk tes Keterampilan berpikir Kritis peserta didik. Selama proses pembelajaran diterapkan model pembelajaran inkuiri terbimbing pada kelompok eksperimen dan kelompok kontrol. Namun, pada kelompok eksperimen digunakan media animasi sedangkan pada kelompok kontrol tanpa media animasi.

Instrumen yang digunakan pada penelitian ini yaitu tes. Tes digunakan untuk mengumpulkan data guna mengetahui hasil belajar peserta didik dan untuk melihat keterampilan berpikir kritis diakhir pembelajaran yang disusun berdasarkan indikator berpikir kritis. Soal tes uraian berjumlah 15 nomor terbagi dalam 3 kode soal, masing-masing kode terdiri dari 5 soal. Namun sebelum digunakan dilakukan validasi terlebih dahulu yaitu validasi ahli. Selain itu di gunakan juga lembar observasi untuk mengetahui proses pembelajaran yang disusun berdasarkan indikator berpikir kritis dan aktivitas belajar peserta didik.

Data diperoleh dari hasil tes keterampilan berpikir kritis peserta didik dari kelompok eksperimen dan kelompok kontrol dengan pemberian tes yang sama yang dilakukan pada akhir pokok bahasan kesetimbangan kimia (post-tes). Pemberian skor dilakukan berdasarkan kriteria penskoran yang disusun berdasarkan indikator keterampilan berpikir kritis.

Analisis hasil tes keterampilan berpikir kritis peserta didik mula-mula dilakukan dengan menentukan skor pada setiap indikator dan skor tiap soal sesuai dengan kriteria penskoran yang telah ditetapkan berdasarkan indikator keterampilan berpikir kritis peserta didik.

Hasil analisis keterampilan berpikir kritis yang diperoleh peserta didik selama proses pembelajaran di kategorikan sebagai berikut:

Tabel 1 Kriteria Keterampilan Berpikir Kritis

\begin{tabular}{|c|c|}
\hline $\begin{array}{c}\text { Persentase } \\
\text { keterampilan } \\
\text { berpikir kritis (\%) }\end{array}$ & Kategori \\
\hline $81-100$ & Kritis Sekali \\
\hline $66-80$ & Kritis \\
\hline $56-65$ & Cukup Kritis \\
\hline $41-55$ & Kurang Kritis \\
\hline $0-40$ & Tidak Kritis \\
\hline
\end{tabular}


Arikunto 2001 (Dalam Dewi 2012).

Analisis statistik deskriptif adalah analisis yang digunakan untuk menganalisis data dengan cara mendeskripsikan data yang telah terkumpul tanpa membuat kesimpulan yang berlaku untuk umum atau generalisasi. Analisis statistik deskriptif meliputi penyajian data melalui tabel, perhitungan mean, modus, median, dan standar deviasi.

Untuk menguji hipotesis, terlebih dahulu dilakukan uji normalitas data dan homogenitas variansi. Kemudian dilanjutkan pengujian hipotesis untuk mengetahui ada tidaknya pengaruh media animasi dalam model pembelajaran inkuiri terbimbing terhadap keterampilan berpikir kritis dan aktivitas belajar peserta didik pada materi kesetimbangan kimia.

\section{HASIL DAN PEMBAHASAN Hasil Penelitian}

Data nilai keterampilan berpikir kritis merupakan hasil belajar peserta didik pada materi kesetimbangan kimia yang kemudian dianalisis secara deskriptif meliputi penyajian tabel, diagram, nilai rata-rata (mean), nilai tertinggi, nilai terendah, median, modus, varians dan standar deviasi. Data hasil analisis statistik deskriptif dapat dilihat pada tabel 2.

Tabel 2 Nilai Statistik deskriptif hasil belajar Peserta didik pada kelompok eksperimen dan kelompok kontrol

\begin{tabular}{|l|c|c|}
\hline \multirow{2}{*}{ Statistik } & \multicolumn{2}{|c|}{ Nilai Statistik } \\
\cline { 2 - 3 } & $\begin{array}{c}\text { Kelompok } \\
\text { Eksperimen }\end{array}$ & $\begin{array}{c}\text { Kelompok } \\
\text { Kontrol }\end{array}$ \\
\hline Jumlah sampel & 37 & 39 \\
\hline Nilai terendah & 64,40 & 60,00 \\
\hline Nilai tertinggi & 93,80 & 88,60 \\
\hline $\begin{array}{l}\text { Nilai rata-rata } \\
\text { (mean) }\end{array}$ & 81.35 & 70,53 \\
\hline Median (Me) & 82.04 & 68.15 \\
\hline Modus (Mo) & 82 & 65.75 \\
\hline Varians (S $\left.{ }^{2}\right)$ & 60.62 & 52.99 \\
\hline $\begin{array}{l}\text { Standar deviasi } \\
\text { (S) }\end{array}$ & 7,78 & 7,27 \\
\hline
\end{tabular}

Tabel 2 diatas menunjukkan bahwa ada perbedaan secara jelas yang terlihat pada nilai tes hasil belajar peserta didik untuk kelompok eksperimen dan kelompok kontrol.

Jika keterampilan berpikir kritis peserta didik dikelompokkan berdasarkan tiap pencapaian indikator, maka hasilnya dapat dilihat pada Tabel 3 .

Tabel 3 Data hasil keterampilan berpikir kritis peserta didik Tiap Indikator Pada Kelompok Eksperimen dan Kelompok Kontrol

\begin{tabular}{|c|c|c|c|}
\hline \multirow[t]{2}{*}{ No. } & \multirow{2}{*}{$\begin{array}{c}\text { Indikator } \\
\text { Keterampilan } \\
\text { Berpikir } \\
\text { Kritis }\end{array}$} & \multicolumn{2}{|c|}{ Presentase Peserta Didik } \\
\hline & & $\begin{array}{c}\text { Kelompok } \\
\text { Eksperimen }\end{array}$ & $\begin{array}{c}\text { Kelompok } \\
\text { Kontrol }\end{array}$ \\
\hline 1 & $\begin{array}{l}\text { Memberikan } \\
\text { penjelasan } \\
\text { sederhana }\end{array}$ & $79.36 \%$ & $72.69 \%$ \\
\hline 2 & $\begin{array}{l}\text { Membangun } \\
\text { keterampilan } \\
\text { dasar }\end{array}$ & $80.97 \%$ & $69.89 \%$ \\
\hline 3 & $\begin{array}{l}\text { Mengatur } \\
\text { strategi dan } \\
\text { taktik }\end{array}$ & $85.81 \%$ & $73.60 \%$ \\
\hline 4 & $\begin{array}{l}\text { Memberikan } \\
\text { penjelasan } \\
\text { lebih lanjut }\end{array}$ & $79.50 \%$ & $68.31 \%$ \\
\hline 5 & Menyimpulkan & $82.72 \%$ & $67.01 \%$ \\
\hline
\end{tabular}

Dari tabel diatas terlihat bahwa pencapaian keterampilan berpikir kritis peserta didik untuk indikator 1, 2, 34 dan 5 pada kelompok eksperimen lebih tinggi dibandingkan pencapaian pada kelompok kontrol. Pencapaian Keterampilan berifikir kritis peserta didik untuk tiap indikator pada kelompok eksperimen dan kelompok kontrol digambarkan dalam diagram batang pada Gambar 1 berikut:

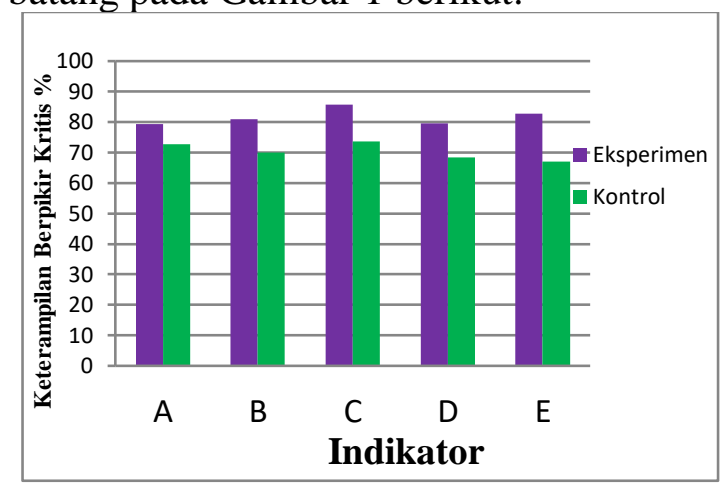


Gambar 1 Diagram Pencapaian Keterampilan berpikir kritis Peserta didik Tiap Indikator Pada Kelompok Eksperimen dan Kelompok Kontrol

Keterangan:

$\mathrm{A}=$ Memberikan penjelasan sederhana

$\mathrm{B}=$ Membangun keterampilan dasar

$\mathrm{C}=$ Mengatur strategi dan taktik

$\mathrm{D}=$ Memberikan penjelasan lebih lanjut

$\mathrm{E}=$ Menyimpulkan

Gambar 1 diatas menunjukkan

bahwa persentase indikator keterampilan berpikir kritis peserta didik tertinggi pada kelompok eksperimen dan kelompok kontrol adalah indikator 3 (mengatur strategi dan taktik) sedangkan persentase indikator keterampilan berpikir kritis terendah untuk kelompok eksperimen adalah indikator 1 (memberikan penjelasan sederhana) sedangkan untuk kelompok kontrol adalah indikator 5 (menyimpulkan). Gambar 1 juga menunjukkan bahwa persentase indikator keterampilan berpikir kritis 1, 2, 3, 4 dan 5 pada kelompok eksperimen lebih tinggi dibandingkan kelompok kontrol.

Berdasarkan data analisis yang diperoleh bahwa rata-rata persentasi keterampilan berpikir kritis peserta didik kelompok eksperimen adalah 81,35 \% sedangkan kelompok kontrol 70,53\%, jadi dapat dikatakan bahwa kelompok eksperimen maupun kelompok kontrol dapat berpikir kritis pada saat proses pembelajaran berdasarkan Tabel 1 .

Analisis stratistik inferensial digunakan untuk menguji hipotesis penelitian yaitu pengaruh Media animasi dalam Model pembelajaran inkuiri terbimbing terhadap keterampilan berpikir kritis dan aktivitas belajar peserta didik. Namun Sebelum uji hipotesis, terlebih dahulu dilakukan uji prasyarat yaitu uji normalitas dan uji homogenitas.

\section{a) Uji Normalitas}

Uji normalitas yang digunakan dalam penelitian ini adalah uji Chi kuadrat. Dari hasil perhitungan untuk kelompok eksperimen, didapatkan nilai $\chi^{2}$ hitung $=-7,591$ dan nilai $\chi_{\text {tabel }}^{2}$ untuk $\mathrm{dk}=3$ pada taraf signifikansi 0,05 adalah 7,815 untuk kelompok eksperimen nilai $\chi_{\text {hitung }}^{2}$ $\chi_{\text {tabel, maka data dari kelompok }}^{2}$ eksperimen berasal dari populasi yang berdistribusi normal. Sedangkan kelompok kontrol diperoleh nilai $\chi_{\text {hitung }}^{2}=-43,429$ dan $\chi_{\text {tabel }}^{2}$ pada taraf signifikansi 0,05 dengan $\mathrm{dk}=3$ diperoleh 7,815. Karena nilai $\chi^{2}$ hitung $<\chi^{2}$ tabel, maka data dari kelompok kontrol berasal dari populasi yang berdistribusi normal. Pengolahan uji normalitas data secara manual.

\section{b) Uji Homogenitas}

Uji homogenitas digunakan untuk mengetahui apakah kedua kelompok data yang diteliti berasal dari populasi yang homogen atau tidak. Kriteria pengujian, jika $\mathrm{F}_{\text {hitung }}<\mathrm{F}_{\text {tabel }}$ maka varians kelompok eksperimen dengan varians kelompok kontrol berasal dari populasi yang homogen. Dari hasil perhitungan diperoleh nilai $\mathrm{F}_{\text {hitung }}=1,14$ dan $\mathrm{F}_{\text {tabel }}=1,73$ pada taraf signifikansi 0,05 . Karena $F_{\text {hitung }}<$ $\mathrm{F}_{\text {tabel, }}$ maka disimpulkan bahwa varians kelompok eksperimen dengan varians kelompok kontrol berasal dari populasi yang homogen. Pengolahan uji homogenitas secara manual.

\section{c) Uji Hipotesis}

Perhitungan uji hipotesis dilakukan untuk mengetahui ada atau tidaknya pengaruh Media animasi dalam model pembelajaran inkuiri terbimbing terhadap keterampilan berpikir kritis dan aktivitas belajar peserta didik. Pengujian hipotesis dalam penelitian ini dilakukan dengan uji satu pihak dengan perumusan hipotesis sebagai berikut :

$$
\begin{aligned}
& H_{0}: \mu_{1} \leq \mu_{2} \\
& H_{1}: \mu_{1}>\mu_{2}
\end{aligned}
$$

Hasil perhitungan uji $t$ yang disajikan secara manual, diperoleh nilai $\mathrm{t}_{\text {hitung }}=180,33$ dan nilai $\mathrm{t}_{\text {tabel }}=1,67$ pada taraf signifikansi 0,05 . Dengan membandingkan nilai thitung dan $\mathrm{t}_{\text {tabel }}$ diperoleh $t_{\text {hitung }}>t_{\text {tabel}}$, artinya $\mathrm{H}_{0}$ ditolak dan $\mathrm{H}_{1}$ diterima. Dengan demikian, dapat disimpulkan bahwa Media animasi dalam 
model pembelajaran inkuiri terbimbing berpengaruh terhadap keterampilan berpikir kritis dan Aktivitas Belajar Peserta Didik kelas XI SMA Negeri 21 Makassar pada Materi Kesetimbangan Kimia.

Berdasarkan hasil penelitian yang telah dilakukan di SMA Negeri 21 Makassar diketahui bahwa aktivitas belajar peserta didik tiap pertemuan mengalami peningkatan lebih baik yaitu pada kelompok eksperimen maupun kelompok kontrol. Hasil penelitian aktivitas belajar peserta didik dapat dilihat pada Tabel 3 dan 4.

Tabel 3 Aktivitas Belajar Peserta didik pada Kelas Eksperimen Tiap Pertemuan

\begin{tabular}{|c|c|c|c|c|c|c|}
\hline \multirow{2}{*}{$\begin{array}{c}\text { In } \\
\text { di } \\
\text { kator }\end{array}$} & \multicolumn{5}{|c|}{ Kelompok Eksperimen } \\
\cline { 2 - 7 } $\begin{array}{c}\text { Akt } \\
\text { iv } \\
\text { itas }\end{array}$ & $\begin{array}{c}\text { P1 } \\
\text { Rata- } \\
\text { rata }\end{array}$ & $\begin{array}{c}\text { Per } \\
\text { sen } \\
\text { tase } \\
(\%)\end{array}$ & $\begin{array}{c}\text { Rata- } \\
\text { rata }\end{array}$ & $\begin{array}{c}\text { Per } \\
\text { sen } \\
\text { tase } \\
(\%)\end{array}$ & $\begin{array}{c}\text { Rata- } \\
\text { rata }\end{array}$ & $\begin{array}{c}\text { Per } \\
\text { sen } \\
\text { tase } \\
(\%)\end{array}$ \\
\hline 1 & 3 & 64.86 & 3.5 & 75.67 & 4 & 86.48 \\
\hline 2 & 3.25 & 70.27 & 3.75 & 81.08 & 4 & 86.48 \\
\hline 3 & 3.25 & 70.27 & 3.75 & 81.08 & 4 & 86.48 \\
\hline 4 & 3.5 & 75.67 & 3.5 & 75.67 & 4 & 86.48 \\
\hline 5 & 3.25 & 70.27 & 3.75 & 81.08 & 4 & 86.48 \\
\hline 6 & 3 & 64.86 & 3.5 & 76.67 & 4 & 86.48 \\
\hline 7 & 3.25 & 70.72 & 3.75 & 81.08 & 3.75 & 81.08 \\
\hline 8 & 2.75 & 59.45 & 2.75 & 59.45 & 4 & 86.48 \\
\hline Jumlah & & 545.92 & & 611.78 & & 686.44 \\
\hline Rata-rata & $\mathbf{6 8 . 2 4}$ & & $\mathbf{7 6 . 4 7}$ & & $\mathbf{8 5 . 8 0}$ \\
\hline
\end{tabular}

Tabel 4 Aktivitas Belajar Peserta didik pada Kelompok Kontrol Tiap Pertemuan

\begin{tabular}{|c|c|c|c|c|c|c|}
\hline \multirow{2}{*}{$\begin{array}{c}\text { Indi } \\
\text { ka } \\
\text { tor }\end{array}$} & \multicolumn{5}{|c|}{ Kelompok Kontrol } \\
\cline { 2 - 7 } $\begin{array}{c}\text { Ak } \\
\text { ti } \\
\text { vitas }\end{array}$ & $\begin{array}{c}|c| \\
\text { Rata- } \\
\text { rata }\end{array}$ & $\begin{array}{c}\text { Persen } \\
\text { tase } \\
(\%)\end{array}$ & $\begin{array}{c}\text { Rata- } \\
\text { rata }\end{array}$ & $\begin{array}{c}\text { Persen } \\
\text { tase } \\
(\%)\end{array}$ & $\begin{array}{c}\text { Rata- } \\
\text { rata }\end{array}$ & $\begin{array}{c}\text { Persen } \\
\text { tase } \\
(\%)\end{array}$ \\
\hline 1 & 3 & 61.53 & 3 & 61.53 & 4 & 82.05 \\
\hline 2 & 3 & 61.53 & 3 & 61.53 & 4 & 82.05 \\
\hline 3 & 3 & 61.53 & 3 & 61.53 & 3.75 & 76.92 \\
\hline
\end{tabular}

\begin{tabular}{|c|c|c|c|c|c|c|}
\hline 4 & 3 & 61.53 & 3 & 61.53 & 4 & 82.05 \\
\hline 5 & 2.75 & 56.41 & 2.75 & 56.41 & 4 & 82.05 \\
\hline 6 & 3 & 61.53 & 3 & 61.53 & 4 & 82.05 \\
\hline 7 & 3.25 & 66.66 & 3.25 & 66.66 & 3.75 & 76.92 \\
\hline 8 & 3 & 61.53 & 3 & 61.53 & 4 & 82.05 \\
\hline Jumlah & & 492.25 & & 492.25 & & 646.14 \\
\hline \multicolumn{2}{|c|}{ Rata-rata } & $\mathbf{6 1 . 5 3}$ & & $\mathbf{6 1 . 5 3}$ & & $\mathbf{8 0 . 7 6}$ \\
\hline
\end{tabular}

Berdasarkan Tabel 3 dapat dilihat bahwa keaktifan peserta didik pada pertemuan 1 dan 2 sudah tergolong baik, sebagaimana terlihat pada indikator 1-7 hampir seluruhnya aktivitas yang dijabarkan peneliti dalam kategori baik. Indikator efektivitas pemanfaatan waktu adalah peserta didik dalam pembelajaran masih kurang aktif atau dalam kategori cukup, rata-rata nilai aktivitas yang diperoleh peserta didik pada pertemuan 1 dan 2 yaitu 68.24 dan 76.47 (61\%-80\%) berdasarkan gambar 2, dalam kategori baik. Aktivitas pembelajaran peserta didik pada pertemuan 3, diketahui seluruh peserta didik sudah aktif terlibat dalam pembelajaran. Kondisi tersebut terlihat pada indikator 2-8 rata-rata nilai peserta didik tergolong sangat baik yaitu 85.80 (81\%-100\%) dalam kategori sangat baik.

Aktivitas belajar pada kelompok kontrol (Tabel 4) pada pertemuan 1 dan 2, pembelalajaran peserta didik tergolong aktif. Peserta didik terlibat dalam proses pembelajaran, hal tersebut terlihat pada indikator 1-8 seluruh aktivitas yang dijabarkan oleh peneliti tergolong dalam kategori baik, tetapi persentase yang diperoleh berbeda-beda disetiap indikatornya seperti dalam kegiatan Peserta didik melihat, mengamati, mendengar, partisipasi peserta didik dalam aktivitas belajar, hubungan antar peserta didik dan efektivitas pemanfaatan waktu nilai persentasenya hanya mencapai (61,53\%), motivasi, ketekunan dan antusias peserta didik nilai persentase yang diperoleh hanya $(56.41 \%)$, sedangkan hubungan peserta didik dengan guru nilai 
persentase yang diperoleh adalah $(66.66 \%)$. Nilai rata-rata aktivitas yang diperoleh peserta didik pada pertemuan 1 dan 2 sama yaitu $61.53(61 \%-80 \%)$ dalam kategori baik.

Aktivitas pembelajaran peserta didik pertemuan ke-3, keaktifan pembelajaran peserta didik dalam kategori baik yang terlibat dalam proses pembelajaran terlihat pada indikator 1-8 yaitu dalam kegitan peserta didik mendengar dan hubungan dengan guru, nilai persentasenya sama yaitu rata-rata $76.92(61 \%-80 \%)$ dalam kategori baik. Sedangkan keaktifan peserta didik dalam kategori sangat baik yaitu dalam kegiatan melihat, mengamati, berpartisipasi, motivasi, hubungan antar peserta didik dan efektivitas pemanfaatan waktu, nilai persentasenya sama yaitu rata-rata 82.05 (81\%-100\%) dalam kategori sangat baik. Nilai rata-rata aktivitas peserta didik pada pertemuan 3 mengalami peningkatan yaitu 80,76 (61\%-80\%) dalam kategori baik.

Visualisasi aktivitas belajar peserta didik kelompok eksperimen dan kelompok kontrol dapat dilihat pada gambar 2 dan 3

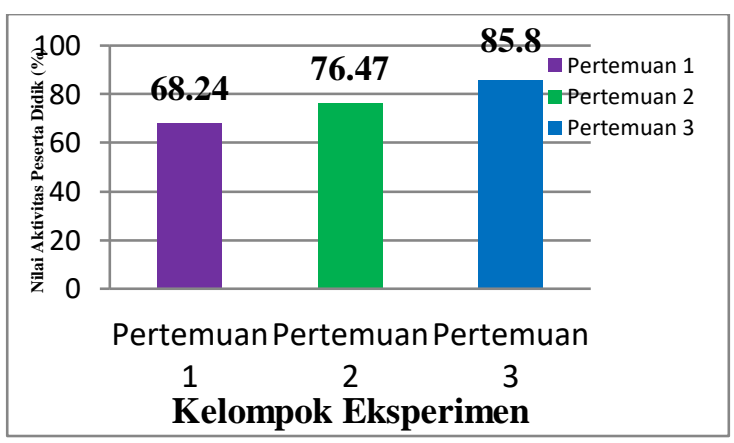

Gambar 2 rata-rata nilai aktivitas peserta didik kelompok eksperimen

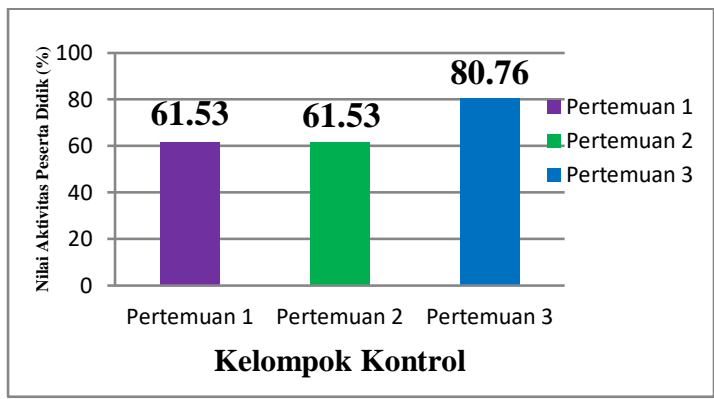

Gambar 3 rata-rata nilai aktivitas peserta didik kelompok kontrol

Berdasarkan Gambar 2 dan 3 diatas menunjukkan bahwa aktivitas belajar peserta didik pada kelompok eksperimen sebagian nilai aktivitas peserta didik lebih baik yaitu dengan rata-rata petemuan pertama (68.24\%), pertemuan kedua $(76.47 \%)$ dan pertemuan ketiga $(85.80 \%)$. Sedangkan pada kelompok kontrol tergolong aktif. Nilai aktivitas belajar peserta didik pada kelompok kontrol yaitu nilai rata-rata pertemuan pertama dan kedua sama $(61.53 \%)$ dan pertemuan ketiga $(80,76 \%)$.

\section{Pembahasan}

Hasil wawancara awal dari keterangan guru kimia mengungkapkan bahwa kemampuan peserta didik kelas XI masih kurang pada mata pelajaran kimia, hal ini terlihat dari sulitnya peserta didik menganalisis soal-soal kimia. Materi kesetimbangan kimia dalam pembelajaran kimia merupakan materi yang banyak mengandung konsep-konsep yang perlu dipahami peserta didik. Materi kesetimbangan kimia menuntut pemahaman, keterampilan dan latihan. Jika peserta didik tidak menguasai konsep maka tidak akan dapat membangun pengetahuan dan akibatnya dalam proses pembelajaran, mereka akan mengalami kesulitan. Media animasi dalam model pembelajaran inkuiri terbimbing sebagai salah satu solusi untuk membangun pengetahuan peserta didik dengan menemukan sendiri konsep dalam materi kesetimbangan kimia.

\section{Pengaruh Media Animasi dalam model Pembelajaran inkuiri terbimbing terhadap keterampilan berpikir kritis Peserta didik}

Penelitian ini dilakukan untuk mengetahui adanya pengaruh media animasi dalam model pembelajaran inkuiri terbimbing terhadap keterampilan berpikir kritis dan aktivitas belajar Peserta didik pada materi kesetimbangan kimia. 
Penelitian ini terdiri dari dua kelompok (kelompok eksperimen dan kontrol) diberikan perlakuan yang berbeda. Kelompok eksperimen dengan menggunakan media animasi sedangkan kelompok kontrol tanpa media animasi.

Berdasarkan data hasil analisis keterampilan berpikir kritis Peserta didik pada proses pembelajaran dapat terlihat persentase dari setiap indikator di kedua kelompok tersebut sangat beragam. Ini berarti pola pemikiran dari Peserta didik SMAN 21 Makassar berbeda-beda, tetapi dapat terlihat pula di setiap indikator kelompok eksperimen memiliki persentase indikator berpikir kritis lebih tinggi dibandingkan kelompok kontrol berdasarkan Tabel 3. Hal ini juga senada dengan hasil penelitiannya Rosita (2013) menyatakan bahwa model pembelajaran inkuiri terbimbing dengan perangkat pembelajaran media animasi mampu membangun pengetahuan dan keterampilan berpikir kritis Peserta didik dengan menemukan sendiri konsep dalam materi kesetimbangan kimia.

Persentase Indikator pertama (Memberikan penjelasan sederhana) pada kelompok eksperimen lebih tinggi daripada kelompok kontrol yaitu masing-masing $79,36 \%$ dan $72,69 \%$. Hal ini menunjukkan bahwa model pembelajaran inkuiri terbimbing dengan perangkat pembelajaran media animasi dapat meningkatkan keterampilan berpikir kritis Peserta didik dalam mengidentifikasi argument. Hal ini juga senada dengan hasil penelitiannya Nila Retnosari (2016) menyatakan bahwa model pembelajaran inkuiri terbimbing dapat mengarahkan peserta didik untuk memecahkan masalah yang diberikan dengan menghubungkan atau mengaplikasikan pengetahuan kimianya untuk dapat meningkatkan keterampilan berpikir kritis. Berpikir kritis menggunakan dasar proses berpikir untuk menganalisis argumen dan memunculkan wawasan terhadap tiap makna dan interpretasi, untuk mengembangkan pola penalaran yang kohesif dan logis, memahami asumsi dan bisa mendasari tiap posisi.

Indikator selanjutnya (Membangun keterampilan dasar) tentang suatu penjelasan atau tantangan, persentase pada kelompok eksperimen juga lebih tinggi daripada kelompok kontrol yaitu untuk kelompok eksperimen $80.97 \%$ dan kelompok kontrol $69.89 \%$ sebab pada penyelesaian masalah dalam pembelajaran inkuiri terbimbing dengan bantuan media animasi secara bertahap dapat membantu Peserta didik untuk mengorganisasikan pengetahuannya. Hal ini senada dengan penelitian Pusporini (2012) yang mengatakan bahwa Peserta didik yang memiliki keterampilan berpikir kritis tinggi memiliki rasa ingin tahu yang besar untuk belajar dan berusaha untuk berpikir secara logis dalam rangka memecahkan masalah, dengan cara bertanya maupun mencari sendiri pemecahannya. Sedangkan Dalam studi Plass dkk (1998) media animasi sebagai alat bantu Peserta didik agar lebih tertarik dan termotivasi dalam kegiatan pembelajaran, karena penyajian materi pembelajaran lebih memotivasi peserta didik. Peran media animasi sebagai proses berpikir kritis peserta didik, topik yang dipelajari secara luas digambarkan dalam media animasi, hasil ini bisa ditafsirkan dengan baik sehingga media animasi memiliki potensi untuk membantu peserta didik memvisualisasikan proses dengan menyediakan informasi yang dibutuhkan.

$\begin{array}{llr}\text { Mengatur } & \text { strategi dan taktik } \\ \text { (Membuat } & \text { keputusan } & \text { dan } \\ \text { mempertimbangkan } & \text { hasilnya) } & \text { disini }\end{array}$
Peserta didik membuat keputusan dengan mengaitkan konsep satu sama lain dengan pemahaman yang dimilikinya sehingga bisa mendapatkan hasil yang baik. Menurut Sriwenda (2013) pemahaman yang baik dan benar tentang materi khususnya kesetimbangan kimia dapat meningkatkan hasil belajar Peserta didik. Keterampilan Peserta didik dalam Membuat Keputusan dan mempertimbangkan hasilnya ini dapat dikembangkan melalui proses 
pembelajaran dengan model pembelajaran inkuiri terbimbing berbantuan media animasi. Hal ini terlihat pada persentase indikator Membuat Keputusan dan mempertimbangkan hasilnya pada kelompok eksperimen lebih tinggi daripada kelompok kontrol yaitu masing-masing $85.81 \%$ dan $73.60 \%$. Hal ini juga senada dengan hasil penelitiannya Susilo (2016) menyatakan bahwa nilai peserta didik yang dibelajarkan dengan model pembelajaran inkuiri terbimbing berbantuan media animasi dalam Membuat Keputusan dan Mempertimbangkan hasilnya pada kelompok eksperimen lebih tinggi nilainya daripada kelompok kontrol dibelajarkan secara konvensional (secara langsung).

Memberikan penjelasan lebih lanjut (mengidentifikasi asumsi), pada indikator ini Peserta didik harus memeriksa atau mengoreksi kemungkinan kesalahan dari berbagai asumsi atau pendapat, kemudian menyelesaikan dan menentukan solusi pemecahan masalahnya. Sejalan dengan itu menurut Ruwaidah (2012) dalam penelitiannya belajar kimia akan lebih di pahami Peserta didik apabila Peserta didik itu sendiri yang melakukan, mengoreksi kesalahan dari suatu pendapat, menemukan, mengkaitkan konsep yang satu dengan yang lainnya dan membuat kesimpulan. Dari hasil persentase indikator Mengidentifikasi asumsi pada kelompok eksperimen lebih tinggi daripada persentase Peserta didik pada kelompok kontrol yaitu masing-masing adalah $79.50 \%$ dan $68.31 \%$, sehingga dapat dikatakan bahwa keterampilan mengidentifikasi masalah dari kelompok eksperimen lebih baik dari Peserta didik di kelompok kontrol.

Indikator keterampilan berpikir kritis yang terakhir adalah indikator Menyimpulkan (memutuskan suatu tindakan). Tercapainya indikator ini sangat bergantung pada indikator sebelumya yang mana sebelum Peserta didik dapat menentukan tindakan yang tepat dia harus bisa menganalisis masalah sampai dengan mengidentifikasinya. Persentase indikator ini Peserta didik pada kelompok eksperimen lebih tinggi daripada persentase Peserta didik pada kelompok kontrol yaitu pada kelompok eksperimen adalah $82.72 \%$ dan kelompok kontrol adalah $67.01 \%$.

Berdasarkan rara-rata hasil analisis keterampilan berpikir kritis pada saat pelaksanaan pembelajaran persentase kelompok eksperiment yaitu $81.67 \%$ dan kelompok kontrol yaitu $70.30 \%$. Dari hasil ini dapat dilihat bahwa persentase tersebut masuk dalam kategori kritis karena terdapat pada rentang 66\% - 80\% (Tabel 1) dan dapat di dikatakan pula bahwa dari data tersebut walaupun masuk dalam kategori yang sama tetapi persentase kelompok eksperimen lebih tinggi dibandingkan kelompok kontrol.

Dari hasil analisis data yang diperoleh rata-rata nilai keterampilan berpikir kritis Peserta didik yang dibelajarkan dengan menggunakan media animasi pada model pembelajaran inkuiri terbimbing lebih tinggi daripada Peserta didik yang dibelajarkan melalui model pembelajaran inkuiri terbimbing tanpa media animasi.

Berdasarkan pengujian prasyarat analisis data, dinyatakan bahwa data dari kelompok eksperimen dan kelompok kontrol berasal dari populasi yang berdistribusi normal dan homogen, sehingga pengujian hipotesis dengan menggunakan uji t dapat dilanjutkan. Hasil pengujian hipotesis dengan menggunakan uji $\mathrm{t}$ memberikan kesimpulan bahwa $\mathrm{H}_{0}$ ditolak dan $\mathrm{H}_{1}$ diterima, artinya media animasi dalam model pembelajaran inkuiri terbimbing dapat mempengaruhi keterampilan berpikir kritis dan aktivitas belajar Peserta didik kelas XI SMA Negeri 21 Makassar pada materi kesetimbangan kimia.

\section{Pengaruh Media Animasi dalam model Pembelajaran inkuiri terbimbing terhadap Aktivitas Belajar Peserta didik}

Berdasarkan tabel 3 aktivitas belajar peserta didik kelompok eksperimen 
pada pertemuan pertama indikator 1 (Peserta didik melihat) memperoleh nilai 64,86\% dan Indikator 2 (Peserta didik mengamati) memperoleh nilai 70,27\%, hal ini disebabkan karena di pertemuan pertama peserta didik masih merasa malu dan enggan dalam melihat dan mengamati video animasi yang ditampilkan oleh guru apabila guru yang bersangkutan tidak memancing peserta didik terlebih dahulu untuk melihat dan mengamati video yang ditampilkan. Hal ini senada dengan penelitian Rohati (2014) menyatakan bahwa faktor yang mempengaruhi rendahnya aktivitas belajar peserta didik salah satunya adalah guru sebagai tenaga pendidikan yang memiliki tugas menyelenggarakan kegiatan belajar mengajar, membimbing, melatih, mengolah, meneliti dan mengembangkan serta memberikan penalaran teknik belum sepenuhnya dapat membuat peserta didik aktif.

Pertemuan kedua dan ketiga indikator 1 dan 3 (Peserta didik melihat dan mendengar) mengalami peningkatan dengan nilai $75,67 \%$ dan $86,48 \%$ untuk indikator 1 (Peserta didik melihat), sedangkan indikator 3 (Peserta didik mendengar) dengan nilai $81,08 \%$ dan $86,48 \%$ dalam kategori sangat baik, hal ini menunjukkan adanya peningktan aktivitas belajar peserta didik yang mulai berani untuk bertanya maupun menjawab materi yang dipaparkan dengan mendengar video animasi yang ditampilkan oleh guru. Menurut Sardiman aktivitas bertanya seperti menyatakan, merumuskan, bertanya, memberi saran, mengeluarkan pendapat, mengadakan wawancara, dan diskusi. Kemudian aktivitas mendengarkan seperti mendengarkan: uraian, percakapan, diskusi, musik, dan pidato adalah jenis aktivitas yang dapat dilakukan oleh peserta didik di sekolah.

Indikator selanjutnya (Partisipasi peserta didik dan Motivasi, ketekunan dan antusiasme peserta didik) pada pertemuan pertama memperoleh nilai $75,67 \%$ dan $70,27 \%$ dalam kategori baik, hal ini disebabkan karena ke-2 indikator tersebut dari keseluruhan peserta didik hanya beberapa peserta didik yang masih kurang berpartisipasi dan motivasi, ketekunan dalam belajar. Sedangkan pada pertemuan kedua dan ketiga mengalami peningkatan dengan memperoleh nilai $75,67 \%$ dan $81,08 \%$ untuk indikator (Partisipasi peserta didik dan Motivasi, ketekunan dan antusiasme peserta didik) pada pertemuan kedua, kemudian pada pertemuan ketiga di indikator yang sama memperoleh nilai yang sama yaitu $86,48 \%$ dalam kategori sangat baik, hal ini disebabkan karena semua peserta didik sudah terlibat sangat aktif dalam berpartisipasi dan motivasi, ketekunan dan antusias saat proses pembelajaran berlangsung. Hal ini juga senada dengan penelitiannnya Kadek Sukiyasa (2013) menyatakan pengaruh media animasi terhadap aktivitas belajar peserta didik akan mengalami peningkatan jika peserta didik ikut berpartisipasi dan termotivasi dalam proses pembelajaran.

Indikator 6 dan 7 (Hubungan antar peserta didik dan Hubungan peserta didik dengan guru) pada pertemuan pertama memperoleh nilai $64,86 \%$ dan $70,72 \%$, hal ini menunjukkan dari keseluruhan peserta didik ada beberapa peserta didik yang memiliki hubungan kurang baik antar peserta didik dalam bekerjasama dengan kelompoknya masing-masing maupun hubungannya dengan guru sehingga keaktifan dalam mengikuti proses pembelajaran menurun. Tetapi pada pertemuan kedua dan ketiga aktivitas belajar peserta didik mengalami peningkatan yaitu pada indikator 6 (Hubungan antar peserta didik) memperoleh nilai $76,67 \%$ dan $86,48 \%$, sedangkan indikator 7 (Hubungan peserta didik dengan guru) memperoleh nilai $81,08 \%$ dan $81,08 \%$ dalam kategori sangat baik, hal ini menunjukkan bahwa adanya peningkatan seluruh peserta didik untuk berperan sangat aktif di dalam kelas baik dari segi kehadiran yang tepat waktu, hubungan antar peserta didik dalam bekerjasama dengan kelompoknya masing- 
masing, serta hubungannya dengan guru sehingga setiap peserta didik terlibat aktif di dalam kelas. Berdasarkan penelitian Meici (2012) menyatakan bahwa dengan adanya keterlibatan peserta didik belajar secara langsung akan meningkatkan interaksi peserta didik dalam mempelajari materi dan memahami materi yang diajarkan. Kondisi tersebut dapat meningkatkan semangat peserta didik dalam mengemukakan pendapat.

Indikator aktivitas belajar yang terakhir adalah indikator 8 (Efektivitas pemanfaatan waktu) pada pertemuan pertama dan kedua memperoleh nilai yang sama yaitu 59,45\% dalam kategori cukup, hal ini disebabkan karena salah satu kelompok mengerjakan tugas kelompoknya masih lambat, sedangkan waktu yang diberikan oleh guru sudah sesuai dengan kesepakatan seluruh peserta didik, hal ini menunjukkan bahwa kelompok tersebut dalam pembagian tugas kelompoknya kurang kompak hanya terfokus kepada satu atau dua orang saja. Sedangkan pada pertemuan ketiga mengalami peningkatan yang lebih baik dengan memperoleh nilai $86,48 \%$. Hal ini menunjukkan bahwa setiap peserta didik mempunyai respon yang baik dan keinginan yang lebih tinggi untuk meningkatkan semangat belajar. Berdasarkan penelitian Dzulkifli (2013) menjelaskan bahwa hasil observasi yang telah dilakukan dengan menggunakan model inkuiri terbimbing (Guide Inquiri) berbantuan multimedia animasi untuk meningkatkan aktivitas dan hasil belajar Kimia dalam dua siklus kegiatan pelaksanaan penelitian, diperoleh data bahwa aktivitas atau keaktifan peserta didik dalam mengikuti kegiatan pembelajaran mengalami peningkatan. Pada siklus I presentasi keaktifan peserta didik $67,43 \%$ sedangkan pada siklus II menjadi $82,02 \%$ meningkat $14,6 \%$. Ini menunjukkan bahwa model inkuiri terbimbing (Guide Inquiri) dapat meningkatkan aktivitas belajar peserta didik.
Berdasarkan Tabel 3 aktivitas belajar peserta didik pada kelompok kontrol indikator 1-4 (Peserta didik melihat, mengamati, mendengar dan partisipasi peserta didik) pada pertemuan pertama dan kedua memperoleh nilai yang sama yaitu $61,53 \%$ dalam kategori baik, hal ini disebabkan karena peserta didik belum terbiasa untuk memberikan pertanyaan dan menjawab pertayaan pada saat proses belajar mengajar, karena selama ini peserta didik hanya mendengar saja penjelasan dari guru dan sistem pembelajarannya masih secara konvensional. Sedangkan pada pertemuan kedua indikator 1-4 (Peserta didik melihat, mengamati, mendengar dan partisipasi peserta didik) mengalami peningkatan dengan memperoleh nilai secara berurutan $(82,05 \%, 82,05 \%, 76,92 \%$, dan $82,05 \%)$ dalam kategori sangat baik, hal ini disebabkan karena ada beberapa orang peserta didik merasa ingin tau dalam proses belajar mengajar maka timbullah pertanyaan dan timbullah jawaban setelah melihat dan mendengarkan apa yang disampaikan oleh guru. Hal ini senada dengan hasil penelitiannya Wahyunita Sari (2014) menyatakan bahwa rasa ingin tau yang tinggi setelah melihat, mengamati dan mendengar apa yang disampaikan oleh guru dapat meningkatkan aktivitas belajar peserta didik dalam proses pembelajaran khususnya pada materi kesetimbangan kimia.

Indikator 5 (Motivasi, ketekunan dan antusiasme peserta didik) pada pertemuan pertama dan kedua memperoleh nilai yang sama yaitu 56,41 \% dalam kategori cukup, sedangkan pada pertemuan ketiga mengalami peningkatan yaitu $82,05 \%$ dalam kategori sangat baik, hal ini disebabkan karena ada beberapa peserta didik bersemangat dalam belajar. Indikator 6 (Hubungan antar peserta didik) pada pertemuan pertama dan kedua memperoleh nilai yang sama yaitu $61,53 \%$ dan indikator 7 (Hubungan peserta didik dengan guru) memperoleh nilai yang sama juga yaitu $66,66 \%$ dalam kategori baik, hal 
ini menunjukkan dari keseluruhan peserta didik ada beberapa peserta didik yang memiliki hubungan kurang baik antar peserta didik dalam bekerjasama dengan kelompoknya masing-masing serta hubungannya dengan guru sehingga keaktifan dalam mengikuti proses pembelajaran menurun, akan tetapi pada pertemuan ketiga aktivitas belajar peserta didik pada indikator yang sama mengalami peningkatan yaitu indikator 6 (Hubungan antar peserta didik) memperoleh nilai $82,05 \%$ dan indikator 7 (Hubungan dengan guru) memperoleh nilai $76,92 \%$ dalam kategori sangat baik, hal ini menunjukkan bahwa adanya peningkatan seluruh peserta didik untuk berperan sangat aktif di dalam kelas baik dari segi kehadiran yang tepat waktu, hubungan antar peserta didik dalam bekerjasama dengan kelompoknya masingmasing, serta hubungannya dengan guru sehingga setiap peserta didik terlibat aktif di dalam kelas. Berdasarkan penelitian Meici (2012) menyatakan bahwa dengan adanya keterlibatan peserta didik belajar secara langsung akan meningkatkan interaksi peserta didik dalam mempelajari materi dan memahami materi yang diajarkan. Kondisi tersebut dapat meningkatkan aktivitas belajar peserta didik.

Indikator aktivitas belajar yang terakhir adalah indikator 8 (Keaktifan pemanfaatan waktu) pada pertemuan pertama dan kedua memperoleh nilai yang sama yaitu $61,53 \%$ dalam kategori baik, hal ini disebabkan karena salah satu kelompok mengerjakan tugas kelompoknya masih lambat, sedangkan waktu yang diberikan oleh guru sudah sesuai dengan kesepakatan seluruh peserta didik, hal ini menunjukkan bahwa kelompok tersebut dalam pembagian tugas kelompoknya kurang kompak hanya terfokus kepada satu atau dua orang saja. Sedangkan pada pertemuan ketiga mengalami peningkatan yang lebih baik dengan memperoleh nilai $82,05 \%$. Hal ini menunjukkan bahwa setiap peserta didik mempunyai respon yang baik dan keinginan yang lebih tinggi untuk meningkatkan semangat belajar.

Berdasarkan hasil penelitiannya Wahyunita Sari (2014) tentang pengaruh media animasi terhadap aktivitas belajar peserta didik, diketahui bahwa media animasi efektif dalam meningkatkan hasil aktivitas belajar peserta didik, media animasi dapat menimbulkan respon positif bagi peserta didik selama proses pembelajaran.

Aktivitas belajar pada kelompok kontrol pertemuan pertama dan kedua memperoleh nilai rata-rata yang sama yaitu $61,53 \%$ dalam kategori baik, setiap indikator aktivitas belajar peserta didik dipertemuan pertama mendapatkan nilai yang berbeda-beda disetiap indikatornya. Hal ini disebabkan karena peserta didik kurang dalam berpartisipasi aktif, dan nilai oberservasi aktivitas peserta didik pada pertemuan ketiga mengalami peningkatan yaitu $80,76 \%$ dengan kategori yang sama yaitu baik. Hal ini terbukti bahwa aktivitas belajar peserta didik di kelompok eksperimen dengan menggunkan media animasi lebih baik jika dibandingkan dengan aktivitas belajar di kelompok kontrol dengan pembelajaran tanpa menggunakan media animasi. Berdasarkan hasil penelitiannya Jefri (2010) menjelaskan bahwa peserta didik yang memiliki aktivitas tinggi akan memiliki prestasi belajar yang lebih baik dari pada peserta didik yang memiliki aktivitas rendah. Peserta didik yang aktivitasnya tinggi memiliki hasil $82 \%$, sedangkan peserta didik yang memiliki aktivitas rendah memiliki hasil $52 \%$. Hal ini telah dibuktikan bahwa adanya perbedaan nilai atau hasil pada kelompok kontrol dan kelompok eksperimen. Nilai aktivitas peserta didik di kelompok eksperimen lebih baik dibandingkan nilai aktivitas peserta didik di kelompok kontrol.

\section{KESIMPULAN}

Berdasarkan analisis data dan pengujian hipotesis yang telah dilakukan dapat disimpulkan bahwa ada pengaruh 
positif media animasi dalam model pembelajaran inkuiri terbimbing terhadap keterampilan berpikir kritis dan aktivitas belajar peserta didik kelas XI SMA Negeri 21 Makassar pada materi kesetimbangan kimia.

\section{DAFTAR PUSTAKA}

Arikunto, S. 2011. Dasar-dasar Evaluasi Pendidikan. Edisi revisi. Jakarta: Bumi Aksara.

Anas, Sudijono. 2009. Pengantar Statistik Pendidikan, Jakarta: Raja Grafindo Persada.

Arsyad, A. 2006. Media Pembelajaran. Jakarta: Raja Grafindo Persada. Danim, Sudarbuan. 1995. Media Komunikasi Pendidikan. Jakarta: Bumi Aksara.

Azmi, Choirina, Unik. 2011. Pengaruh Model Pembelajaran Inkuiri dengan Pendekatan Pictorial Riddle terhadap Kemampuan Berpikir Kritis Siswa. Skripsi, Program Studi Pendidikan Fisika, Fakultas Pendidikan Matematika dan Ilmu Pengetahuan Alam, IKIP PGRI Semarang. Semarang

Carol C, Kulhthan dan Ross J. Todd, 2006, "Guided Inquiry Activity: A. Framework For Learning Through School Libraries ON $21^{\text {st }}$ Century School (Contuctivist Learning and Guided Inquiry)”, Amerika.

Costa. 1988. Developing Mind: California. ASCD

Colburn, Alan. 2000. An Inquiry Primer. California University: Science Scope.

Devi Diyas Sari. (2012). "Penerapan Model Problem Based Learning (PBL) Untuk Meningkatkan Kemampuan Berpikir Kritis Peserta Didik Pada Pembelajaran IPA Kelas VIII SMP Negeri 5 Sleman Tahun Ajaran 2012”. Program Studi Pendidikan IPA UNY.

Dzulkifli, Efendi. 2013. "Penerapan Model Student Facilitator and Explaining pada Perkalian Bilangan Bulat,"
Jurnal Pendidikan Matematika STKIP PGRI Sidoarjo.

Ennis, R.H. (2002). "An Outline of Goals for a Critical Thinking Curriculum and Its Assessment". This is a revised version of a presentation at the Sixth International Conference on Thinking at MIT, Cambridge, MA, July, 1994. http://www.criticalthinking.net/goal s.html. Diakses pada 12 Januari 2015.

Hamalik, O. 2004. Proses Belajar Mengajar. Jakarta: Bumi Aksara.

Handikha, Jefri. 2010. Pembelajaran Fisika Memiliki Inkuiri Terbimbing Dengan Metode Eksperimen Dan Demontrasi Ditinjau Dari Aktivitas Dan Perhatian Siswa. Prodi Pendidikan Fisika, IKIP PGRI Semarang. Semarang.

Herawati, Rosita fitri. 2013. Pembelajaran kimia berbasis multiple representasi ditinjau dari keterampilan awal terhadap prestasi belajar laju reaksi siswa SMA NEGERI 1 Karanganyar tahun pelajaran 2011/2012. Jurnal pendidikan kimia (JPK). No 2.

Hoffler, N. Dkk. 2010. Pengaruh Gaya Belajar Kognitif Visual dari Animasi Instruksional dan Gambar Statis (terjemahan). Jerman: Universitas Kiel.

Kadhafi, Rizky. 2013. Pengembangan Modul Kesetimbangan Kimia Berbasis Inkuiri Terbimbing (Guided Inquiry) Untuk SMK. Universitas Negeri Malang. Malang.

Kalsum, Siti, dkk. 2009. Kimia 2 Kelas XI SMA dan MA. Pusat Perbukuan. Jakarta.

Liliasari., 2005. Scientific Concepts and Generic Science Skills Relationship In The $21^{\text {st }}$ Century Science Education. Seminar Proceeding of The First International Seminar of Science Education., 27 October 2007. Bandung. $13-18$. 
Masita, Meici. 2012. "Peningkatan Aktivitas Belajar Siswa Pada Pembelajaran Matematika Melalui Pendekatan Kontekstual", Jurnal Pendidikan Matematika, STKIP PGRI Sidoarjo.

Plass, Chun, Mayer \& Leuther. 1998. Furthemore, the oppurtunity to Easily Include Videos And Animation. Psychology education.

Pusporini, Sri. 2012. Pembelajaran kimia berbasisi problem solvinf menggunakan laboratorium rill dan virtual ditinjau dari gaya belajar dan kemampunan berpikir kritis siswa. Jurnal inkuiri. No 1.

Rahardian, Dewi, Titah. 2011. Metode The King Kimia Ala Tentor. Wahyumedia. Jakarta.

Rahmawati. 2013. Pengaruh Penggunaan Media Powerpoint Dalam Model Pembelajaran Kooperatif Tipe STAD Terhadap Motivasi, Aktivitas Dan Hasil Belajar Siswa SMA Negeri 1 Sendana Kabupaten Majene. Makassar: PPs Universitas Negeri Makassar.

Retnosari, Nila. 2016. "Pengaruh model pembelajaran inkuiri terbimbing berbantuan multimedia interaktif terhadap berpikir kritis siswa kelas XI SMA Negeri di bojonegoro". Pendidikan Biologi PascasarjanaUniversitas Negeri Malang.

Rohati, 2014. Pengaruh Penggunaan Media Animasi Terhadap Hasil Belajar IPA Siswa Slow Learner, jurnal P3LB2014.

Ruwaidah, titik.2012. Pembelajaran kimia dengan metode problem posing dan pemberian tugas ditinjau dari keterampilan berpikir kritis analisis dan kreativitas siswa. Jurnal inkuiri. No 1.

Rusman, D.R. 2011. Model-Model Pembelajaran Mengembangkan Profesionalisme Guru. Jakarta: PT Rajagrafindo Persada.
Salahuddin, M. $1986 . \quad$ Media Pendidikan.Surabaya: PT. Binallmu.

Salim, A. 2003. Animasi Dengan Flash.(http://learning.Unla.ac.id/pr aktikum/sim-

tutorial/web\%20dan\%20 internet/tutorial\%20flash\%20v4.0. pdf) diakses tanggal 08 agustus 2016.

Sanjaya, W. 2010. Strategi Pembelajaran Berorientasi Standar Proses Pendidikan. Jakarta: Kencana.

Sanjaya. 2015. Strategi Pembelajaran. Jakarta: Kencana Prenada Media Group

Sobihi, Muh dan Siswanto, joko. 2012. Pengaruh Pembelajaran Berbasis Masalah Dan Inkuiri Terbimbing Terhadap Kemampuan Berpikir Kritis Dan Kreatif Siswa. Prodi Pendidikan Fisika, IKIP PGRI Semarang. Semarang.

Smaldino, S. E. 2008. Instruktional Technologhy and Media For Learning. Columbus: Pearson Merrill Prentice Hall.

Sriwenda, Ai. 2013. Penerapan pembelajaran model roblem posing untuk meningkatkan kreativitas dan prestasi belajar siswa pada materi laju reaksi kelas XI IPA 5 SMA NEGERI 1 Boyolali tahun ajaran 2012/2013. Jurnal pendidikan kimia $(J P K)$. No 2.

Susilo. 2016. "Pengaruh model pembelajaran inkuiri terbimbing berbantuan media animasi terhadap keterampilan berpikir kritis siswa". Pendidikan Biologi Pascasarjana-Universitas Negeri Malang.

Sukiyasa, Kadek. 2013. pengaruh media animasi terhadap hasil belajar dan motivasi belajar siswa materi sistem kelistrikan otomotif, jurnal pendidikan vokasi, vol 3/no 1 , (Februari, 2013). 
Sugiyono, Prof. DR. 2013. Metode

Penelitian Pendidikan. Alfabeta:

Bandung.

Suheri, A. 2006. Animasi Multimedia

Pembelajaran. Jurnal Animasi

Pembelajaran.

Tood, Ross J. et. all. 2005. A toolkit and Handbook For Tracking and Assessing Student Learning Outcomes of Guided Inquiry Through The School Library. Rutgers University: Institute for Museum and Library Service.

Uyanto, S. S. 2009. Pedoman Analisis Data SPSS. Jogjakarta: Graha Ilmu.

Yamin, Martinis. 2007. Taktik mengembangkan keterampilan individual siswa. Jakarta: Gaung persada Press. 